\title{
LAND COVER CHANGES IN PROTECTED AREAS OF SLOVAKIA BETWEEN 1990 AND 2018
}

Michaela Žoncová

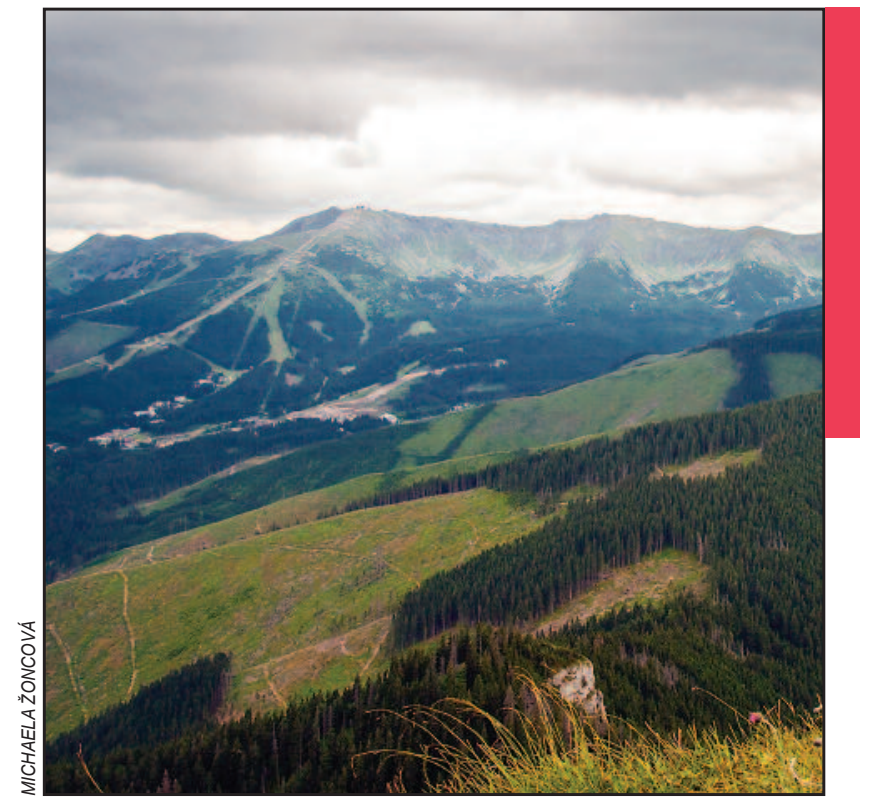

Manifestations of ongoing landscape changes in the National Park Nízke Tatry. 
DOI: https://doi.org/10.3986/AGS.7996

UDC: $913: 711.14(437.6) \ll 1990 / 2018 \ll$

711.14:719(437.6)«1990/2018«

COBISS: 1.01

\section{Michaela Žoncová ${ }^{1}$}

\section{Land cover changes in protected areas of Slovakia between 1990 and 2018}

ABSTRACT: As a country with abundant natural resources, Slovakia has legislation to protect significant parts of nature and landscape. The paper aimed to identify the extent and nature of land cover changes in large protected areas in Slovakia and to determine how had these changes impacted the diversity and ecological stability of the landscape. We used the CORINE Land Cover data from 1990 and 2018 to identify landscape changes and analyzed them spatially and statistically. Overall, $21.7 \%$ of the total area was changed. In terms of landscape changes, nine dominant sub-processes within five »land cover flows « were identified. In terms of changes in landscape diversity and stability the most significant changes occurred in the NP Nízke Tatry.

KEY WORDS: landscape transformation, landscape protection, national park, protected landscape areas, CORINE Land Cover, landscape diversity, landscape stability, Slovakia

\section{Spremembe rabe tal na zavarovanih območjih na Slovaškem med letoma 1990 in 2018}

POVZETEK: Slovaška je bogata $\mathrm{z}$ naravnimi viri in ima zakonodajo, s katero so zavarovana pomembna naravna območja in pokrajine. $V$ članku avtorica proučuje obseg in vrsto sprememb rabe tal na obsežnih zavarovanih območjih na Slovaškem ter ugotavlja, kako so te spremembe vplivale na raznolikost in ekološko ravnovesje pokrajine. Za določanje pokrajinskih sprememb ter njihovo prostorsko in statistično analizo je uporabila podatke CORINE Land Cover za obdobje med letoma 1990 in 2018. Spremenilo se je skupno $21,7 \%$ celotne proučevane površine. Z vidika pokrajinskih sprememb je bilo določenih devet podprocesov znotraj petih tipov sprememb, do največjih sprememb v raznolikosti in ekološkem ravnovesju pokrajin pa je prišlo v Nacionalnem parku Nizke Tatre.

KLJUČNE BESEDE: pokrajinska preobrazba, varovanje pokrajin, narodni park, zavarovana pokrajinska območja, CORINE Land Cover, pokrajinska raznolikost, ekološko ravnovesje pokrajin, Slovaška

The paper was submitted for publication on April 19 $19^{\text {th }}, 2020$.

Uredništvo je prejelo prispevek 19. aprila 2020.

${ }^{1}$ Matej Bel University, Department of Geography and Geology, Banská Bystrica, Slovakia michaela.zoncova@umb.sk (https://orcid.org/0000-0002-1302-9772) 


\section{Introduction}

Slovakia has undergone significant socio-economic changes over the last three decades (namely socialism 1980-1990, postsocialism 1990-2000, EU accession 2000-2006, EU membership 2004-today), which have also affected the land use (Pazúr and Bolliger 2017). The collapse of socialism throughout Eastern Europe was a natural experiment of rare magnitude that affected every aspect of societies, economies and land use practices (Radeloff and Gutman 2017). This rapid transformation is the key factor of understanding landscape changes in Central and Eastern Europe (Urbanc et al. 2004). Land use is determined by natural, socioeconomic, institutional, cultural, and legal factors (Jansen 2006). When the properties of the earth's surface, such as biota, soil, terrain, water, and settlement structure, are added to these factors, we speak of a land cover, which represents the intersection of natural spatial conditions and the current land use (Lambin et al. 2000).

Changes in the protected areas of Slovakia over the given period were manifested mainly in rural areas (Izakovičová 2012) by changes on agricultural land - extensification and abandonment of agricultural land and the decline of traditional land management (Šebo, Kopecká 2004; Lieskovský et al. 2015). Changes in land cover also occurred due to increased urbanization and suburbanization (Pazúr and Bolliger 2017). In protected areas, mostly covered by forests, the changes were caused mainly by natural factors - wind calamities and related problems with bark beetles (Sláviková and Slávik 2006).

Changes due to the increasing importance of tourism have also occurred. Recreational activities can thus be one of the main reasons for disruptions of landscape diversity and stability and increased fragmentation of the landscape caused by the development of tourism may lead to a decrease in biodiversity (Klaučo et al. 2012; Rušnák, Izsóff and Lieskovský 2017; Kňazovičová et al. 2018). Protected areas around the world are crucial to biodiversity conservation (Margules, Pressey and Williams 2002), while land use is a critical factor in providing food and other ecosystem services essential for human needs. The challenge is to identify management opportunities that preserve ecological functions while minimizing human land-use constraints (DeFries et al. 2007). Land cover changes in Europe's protected areas are a frequent research object studied mainly using GIS technologies (e.g., Gabrovec et al. 2013; Zafar 2014; Martinez del Castillo et al. 2015; Janík and Romportl 2018; Hamad, Kolo and Balzter 2018; Krajewski 2019; Martin et al. 2019; Rodríguez-Rodríguez, Martínez-Vega and Echavarría 2019; Ribeiro and Šmid Hribar 2019).

In Slovakia, nature and landscape protection is applied through the Act No.543/2002 Coll. on Nature and Landscape Protection (Zákon o ochrane ... 2002). The Act aims to ensure the long-term preservation of natural balance, the protection of the diversity of conditions and forms of life, natural values and beauty, the creation of conditions for sustainable use of natural resources and ecosystem services, taking into account economic, social and cultural needs as well as regional and local conditions. The range of restrictions increases with the increasing degree of protection. Each type of protected area has a specific degree of protection within its territory. In Slovakia, large and small-scale protected areas are established. A specific degree of protection is applied in different protected areas (Table 1).

The degree of protection of the territory also determines land use and the number of ecosystem services provided. The most dominant industries in the protected areas of Slovakia are forestry, tourism, water management, and mining. The most significant revenues also flow from these industries (Janiga et al. 2012).

Table 1: Protected areas in Slovakia according to the Act No. 543/2002 Coll. on Nature and Landscape Protection.

\begin{tabular}{|c|c|c|c|c|}
\hline Type of protected area & & Degree of protection & Number & Area (ha) \\
\hline \multirow[t]{2}{*}{ Large-scale protected area } & National park (NP) & $3^{\text {rd }}$ & 9 & $317,889.90$ \\
\hline & Protected landscape area (PLA) & $2^{\text {nd }}$ & 14 & $522,581.50$ \\
\hline \multirow[t]{6}{*}{ Small-scale protected area } & National Nature Reserve (NNR) & $4^{\text {th }}, 5^{\text {th }}$ & 219 & $84,188.97$ \\
\hline & Nature Reserve (NR) & $4^{\text {th }}, 5^{\text {th }}$ & 217 & $13,347.35$ \\
\hline & Protected Area (PA) & $3^{\text {rd }}, 4^{\text {th }}, 5^{\text {th }}$ & 166 & 8307.54 \\
\hline & National Nature Monument (NNM) & $4^{\text {th }}, 5^{\text {th }}$ & 11 & $84,188.97$ \\
\hline & Nature Moment (NM) & $4^{\text {th }}, 5^{\text {th }}$ & 217 & 1583.31 \\
\hline & Protected Landscape Feature (PLF) & $2^{\text {nd }}, 3^{\text {rd }}, 4^{\text {th }}, 5^{\text {th }}$ & 1 & 2.51 \\
\hline
\end{tabular}


In our research, we have dealt only with the large-scale protected areas, which cover $22.65 \%$ of Slovakia. A national park is defined as an area of over 10,000 ha, predominantly with ecosystems substantially unchanged by human activity or in a unique and natural landscape structure, constituting the most important natural heritage, in which nature protection is superior to other activities. The protection objective of a national park is the conservation or gradual restoration of natural ecosystems, including ensuring the uninterrupted flow of natural processes in at least three-quarters of the area of a national park. A protected landscape area is defined as an area of over $1000 \mathrm{ha}$, with scattered ecosystems important for the conservation of biodiversity and ecological stability, with a characteristic landscape appearance or with specific forms of historical settlement (Act No. 543/2002 Coll. on Nature and Landscape Protection) (Zákon o ochrane ... 2002). These areas thus constitute representative parts of the landscape that need to be protected by law and focus on their excellent management. Although the legislation protects a large part of the landscape, the protected areas are subject not only to anthropogenic influences but also to various natural disturbances. Protected areas are the cornerstone of forest protection, but during socio-economic and institutional crises, the protection of forests is not always adequate. Since 1990, Slovakia has undergone economic-institutional changes, including the break-up of socialism, accession to the European Union, and the rapid expansion of protected areas (Butsic et al. 2017).

It is very important to detect and analyze changes in protected areas, because they are not immune to biodiversity and habitat loss or increases in human-caused pressure (Geldmann, Joppa and Burgess 2014).

The paper aims to compare and evaluate the extent and the nature of land cover changes in protected areas of Slovakia between 1990 and 2018. Based on the research, we should be able to answer the following research questions:

- What was the extent of changes that took place in selected protected areas of Slovakia?

- What changes took place in protected areas of Slovakia?

- Which land cover classes were dynamic and which were static in protected areas?

- How did the landscape's diversity and stability of protected areas change in the last three decades?

\section{Methods}

\subsection{Study area}

In our research, we have dealt with landscape changes in large-scale protected areas of Slovakia, which include nine national parks and fourteen protected landscape areas (Figure 1).

The oldest protected landscape area is the PLA Vihorlat, which was declared in 1973. All PLAs were established until 1990, except for the PLA Dunajské Luhy, which was established only in 1998 and is the youngest protected area in Slovakia. Some of the present national parks were firstly protected as protected landscape areas and had been transformed into national parks later (1964 - Slovenský raj, 1967 - Malá Fatra, 1973 - Slovenský Kras, 1974 - Vel'ká Fatra, 1977 - Muránska Planina). The oldest national park is the Tatra National Park (TANAP), which was proclaimed in 1948. This year was significant for the former Czechoslovakia, as it had been listed as the $49^{\text {th }}$ state in the list of states that established national parks on their territory (Štátny zoznam osobitne ... 2020). Some protected areas have changed their boundaries and area over time. In our research, we have observed areas delimited by their current borders.

\subsection{Data and analyses}

We have used CORINE Land Cover (CLC) data from 1990 and 2018 for the analysis of land cover changes in protected areas. Using analytical tools in ArcMap 10.5 software, we had been able to identify the extent and the nature of changes over a nearly 30-year period. Twenty-six CLC classes have been identified in large-scale protected areas of Slovakia (Table 2).

We have focused mainly on the comparative evaluation of changes in the individual land cover classes and analyzed them statistically and spatially. The output tables were subsequently transformed into contingency tables, from which we have obtained the proportional shares of land cover classes in 1990 and 
Acta geographica Slovenica, 60-2, 2020

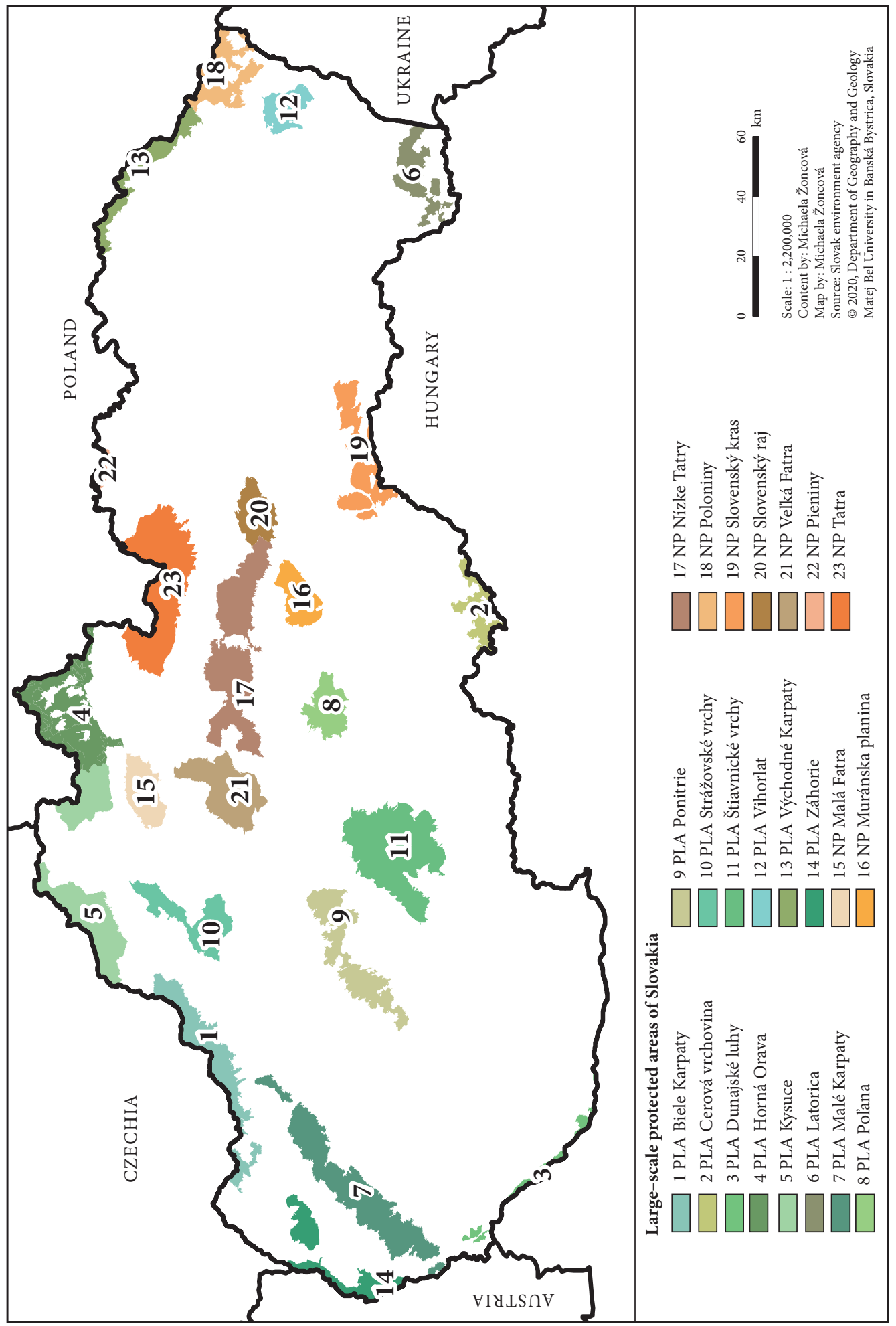


2018 as well as the changes within the period observed. The next stage consisted of assessing landscape structure changes based on the calculation of landscape metrics using the Patch Analyst extension. The software offers analyses of several types of landscape-ecological indices. These metrics are often used as indicators of landscape fragmentation or diversity in Slovakia (Boltižiar 2010; Gajdoš, Klaučo and Škodová 2012; Olahová, Vojtek and Boltižiar 2013) and abroad (Li et al. 2004; Kumar et al. 2018; Deriaz et al. 2019). However, in our research we have focused mainly on the analysis of landscape diversity over time using the Shannon Diversity Index (SDI). It is an index determining landscape diversity calculated as the ratio of the size of different land cover classes over the total area. SDI increases by the number of patches in the land cover classes. The higher the index value, the greater the diversity of the land cover, i.e., the land cover is richer in the number of land cover classes and the number of patches (Klaučo et al. 2014). The index will be equal to 0 when there is only one patch in the landscape, and increases as the number of patch types or the proportional distribution of patch types increases. We analysed the landscape stability using the Ecological Stability coefficient (ESc), according to Míchal (1982). The coefficient reflects the proportion of relatively stable and unstable landscape areas. Stable areas include forests, non-forest tree vegetation, meadows, pastures (we have included CLC classes: 221, 222, 231, 311, 312, 313, 321, 322, 324, 331, 332, 333, 411, 412, 511,512 ). Unstable areas include arable and built-up areas (we have included CLC classes: 112, 121, 131, $132,133,141,412,211,242,243)$. We have observed the values of the coefficient as well as their change between the years 1990 and 2018. The resulting values were interpreted as follows:

- ESc $<0.10$ - an area with a maximal disruption of natural structures, essential ecological functions must be intensively and permanently replaced by technical interventions;

- $\mathrm{ESc}=0.10-0.30$ - an over-exploited area, with an apparent disruption of natural structures;

Table 2: CLC classes in large-scale protected areas of Slovakia.

\begin{tabular}{|c|c|}
\hline Level 1 & Level 3 \\
\hline \multirow[t]{4}{*}{1 Artificial surfaces } & 112 Discontinuous urban fabric \\
\hline & 121 Industrial or commercial units \\
\hline & $\begin{array}{l}131 \text { Mineral extraction sites } \\
132 \text { Dumpsites } \\
133 \text { Construction sites }\end{array}$ \\
\hline & $\begin{array}{l}141 \text { Green urban areas } \\
142 \text { Sport and leisure facilities }\end{array}$ \\
\hline \multirow[t]{4}{*}{2 Agricultural areas } & 211 Non-irrigated arable land \\
\hline & $\begin{array}{l}221 \text { Vineyards } \\
222 \text { Fruit trees and berry plantations }\end{array}$ \\
\hline & 231 Pastures \\
\hline & $\begin{array}{l}242 \text { Complex cultivation patterns } \\
243 \text { Land principally occupied by agriculture, with significant areas of natural vegetation }\end{array}$ \\
\hline \multirow[t]{7}{*}{3 Forest and semi-natural areas } & 311 Broad-leaved forest \\
\hline & 312 Coniferous forest \\
\hline & 313 Mixed forest \\
\hline & 321 Natural grasslands \\
\hline & 322 Moors and heathland \\
\hline & 324 Transitional woodland-shrub \\
\hline & $\begin{array}{l}331 \text { Beaches, dunes, sands } \\
332 \text { Bare rocks } \\
333 \text { Sparsely vegetated areas }\end{array}$ \\
\hline 4 Wetlands & $\begin{array}{l}411 \text { Inland marshes } \\
412 \text { Peat bogs }\end{array}$ \\
\hline 5 Water bodies & $\begin{array}{l}511 \text { Watercourses } \\
512 \text { Waterbodies }\end{array}$ \\
\hline
\end{tabular}


- $\mathrm{ESc}=0.31-1.00$ - an intensively used area, mainly for large-scale agricultural production, where weakening of self-regulatory processes causes their considerable ecological lability;

- ESc $>1,00$ - an almost balanced landscape in which the technical objects are in relative balance with the preserved natural structures.

Within the framework of land cover structure changes between 1990 and 2018, we have also identified the dominant (not the prevailing) process using the »land cover flows (LCF) identification method. Some authors (Stott and Haines-Young 1998; Feranec et al. 2010; Perdigao and Christensen 2000; Köhler, Olschofsky and Gerard 2006) have used this method, but they defined different types of processes. In our research, we used a land cover flow definition by Haines-Young and Weber (2006). They identified nine types of processes:

- LCF1 Urban land management - Internal transformation of urban areas;

- LCF2 Urban residential sprawl - Land uptake by residential buildings altogether with associated services and urban infrastructure from non-urban land;

- LCF3 Sprawl of economic sites and infrastructures - Land uptake by new economic sites and infrastructures (including sport and leisure facilities) from non-urban land;

- LCF4 Agriculture internal conversions - Conversion between farming types;

- LCF5 Conversion from forested \& natural land to agriculture - Agricultural expansion;

- LCF6 Withdrawal of farming - Farmland abandonment and other conversions from agriculture activity in favor of forests or natural land;

- LCF7 Forests creation and management - Creation of forests and management of the forest territory by felling and replanting;

- LCF8 Water bodies creation and management - Creation of dams and reservoirs and possible consequences of the management of the water resource on the water surface area;

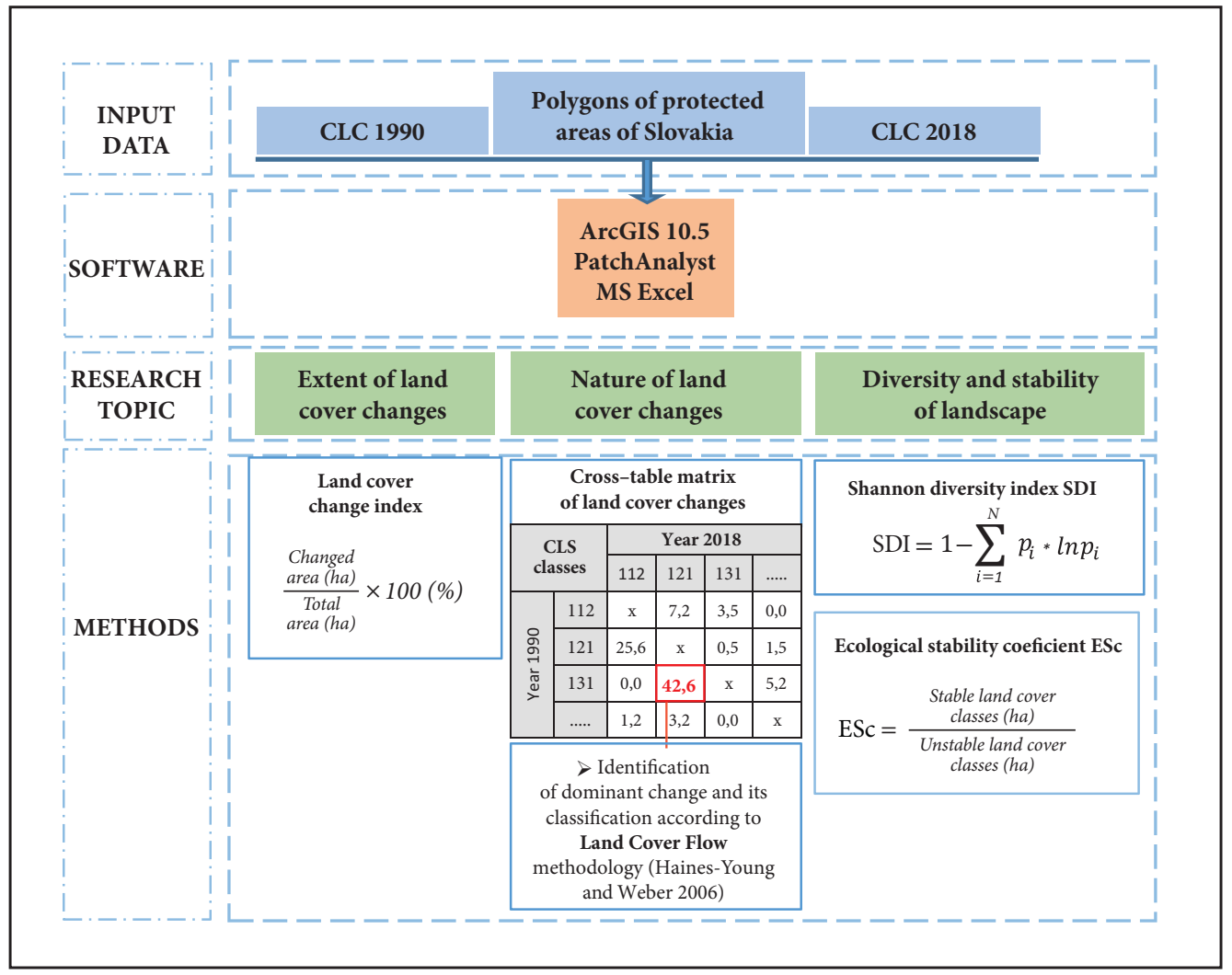

Figure 2: Schematically representation of the methodology followed by the research. 
- LCF9 Changes of land cover due to natural and multiple causes - Changes in land cover resulting from natural phenomena with or without any human influence.

Additionally, Haines-Young and Weber (2006) defined sub-processes at detailed level. For complete list of sub-processes see Haines-Young and Weber (2006). We have identified the most dominant sub-process, i.e., the one with the highest proportional share in each protected area. We have focused on the figure with the highest numerical value, that is to say, which class of land cover was dominantly changing to another class, using the cross table matrix of the changes in the different land cover classes in the observed period. We have then assigned this change to a specific land cover flow. Although we could have assigned other sub-processes in the observed area (e.g., LCF71 includes changes from CLC 324 to CLC 311, CLC 324 to CLC 312, CLC 324 to CLC 313, and other), we have not deliberately addressed all the sub-processes, but only the most dominant sub-process (Figure 2).

\section{Results}

\subsection{The extent of land cover changes}

We could determine the extent of land cover changes by comparing the CLC data from 1990 and 2018 in each of the protected areas (Figure 3).

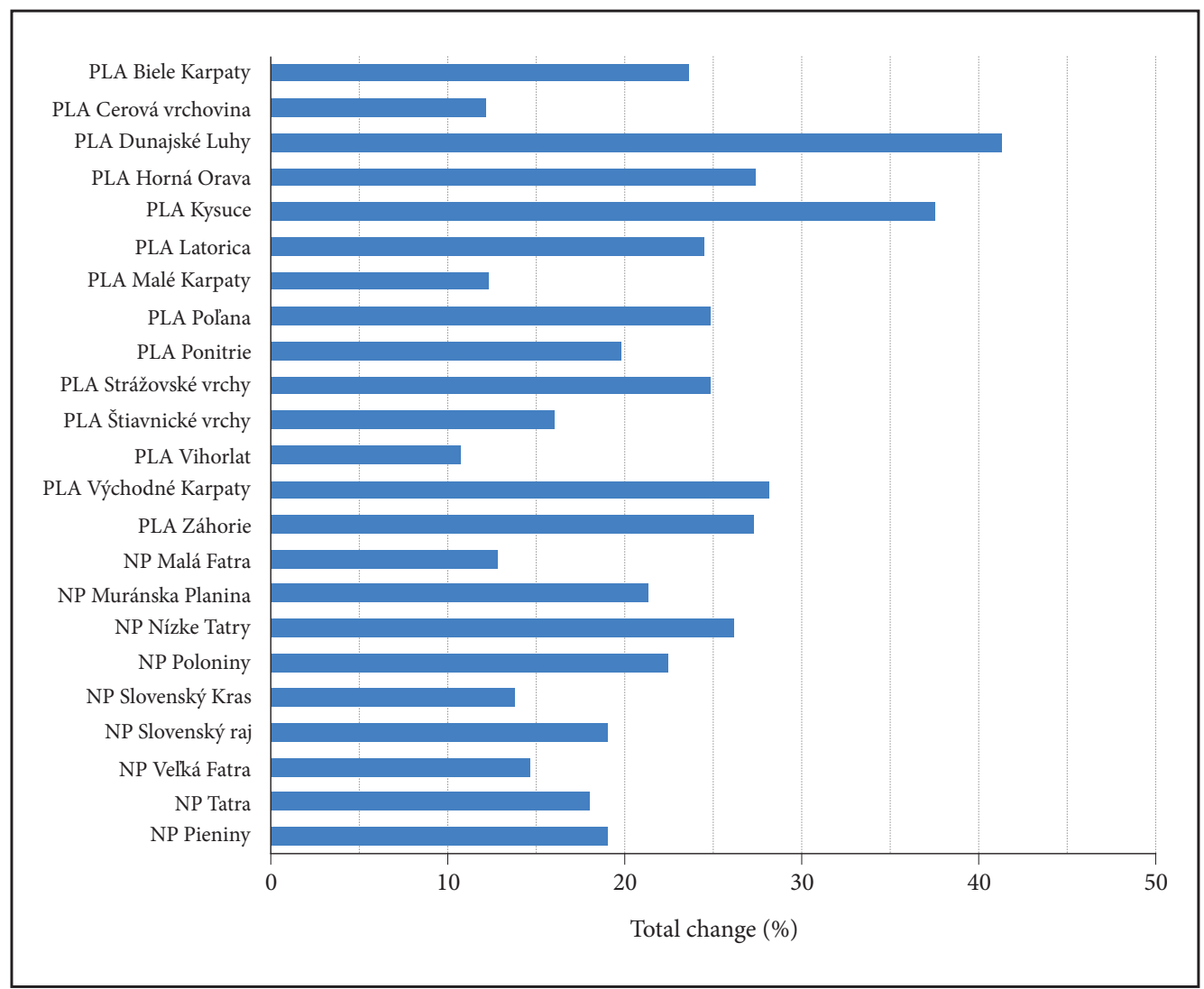

Figure 3: Extent of changes in large protected areas of Slovakia between 1990 and 2018.

Figure 4: Land cover changes in large-scale protected areas in Slovakia between 1990 and 2018 (in \%). 
Acta geographica Slovenica, 60-2, 2020

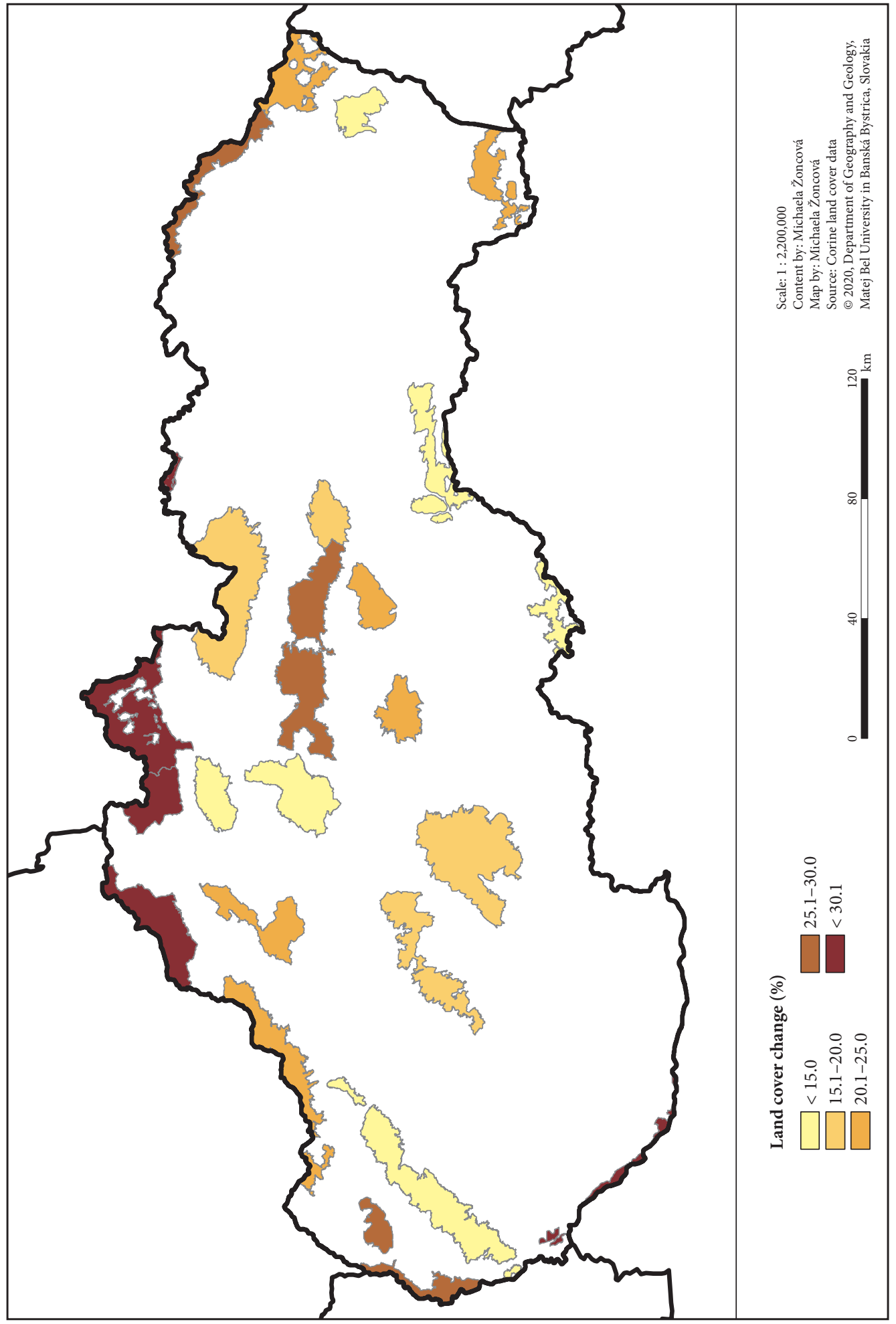


In total, up to $21.7 \%$ of the area of the protected areas was changed. Land cover, and consequently the landscape, changed in the national parks as well as in the protected landscape areas. More than one third of the area was changed in the PLAs Dunajské luhy (41.3\%) and Kysuce (37.6\%). On the contrary, the least changes occurred in the PLAs Vihorlat (10.7\%) and Cerová vrchovina (12.2\%). Considering the national parks, the NP Nízke Tatry has changed the most, where up to $26.3 \%$ of its area has changed. On the contrary, the least changes were recorded in the NP Malá Fatra, where only $12.8 \%$ of the area has changed. In terms of spatial distribution, most changes occurred in protected areas located along the country's borders with one exceptions in the centre of the country in the Low Tatras National Park (Figure 4).

The most significant changes thus took place within CLC classes 231, 243, 311, 312, 313, 324, i.e., within forest stands and meadows. These classes can be considered very dynamic, with more than $20 \%$ decrease or increase in their areal extent. On the contrary, CLC classes 112, 121, 131, 132, 141, 142, 221, 222, 331, $332,333,412$, i.e., urbanized areas, areas of permanent crops, areas with sparse vegetation and wetlands, can be described as static classes.

\subsection{The nature of land cover changes}

By comparing the percentage shares of land cover classes of protected areas in individual years, it is possible to define the nature of the main changes (Table 3).

The most significant increase in land cover class was recorded in the PLA Polana, where up to 58\% of the area was transformed into mixed forests (CLC 313). In particular, the forest land cover classes (CLCs $311,312,324)$ and agricultural land cover classes (CLC 211, 231, 243) were transformed. On the other hand, the most substantial proportional decrease occurred in the PLA Východné Karpaty, where the area of tran-

Table 3: The nature of land cover changes in large protected areas of Slovakia between 1990 and 2018 (x - no change observed).

\begin{tabular}{|c|c|c|c|c|c|c|c|c|c|c|c|c|}
\hline Protected area & 512 & 511 & 412 & 411 & 333 & 332 & 331 & 324 & 322 & 321 & 313 & 312 \\
\hline PLA Biele Karpaty & $x$ & $x$ & $x$ & $x$ & $x$ & $x$ & $x$ & $-5 \%$ & $x$ & $<0.5 \%$ & $-1 \%$ & $-1 \%$ \\
\hline PLA Cerová vrchovina & $-1 \%$ & $x$ & $x$ & $x$ & $x$ & $x$ & $x$ & $-7 \%$ & $x$ & $x$ & $7 \%$ & $1 \%$ \\
\hline PLA Dunajské Luhy & $8 \%$ & $4 \%$ & $x$ & $-5 \%$ & $x$ & $x$ & $<0.5 \%$ & $-44 \%$ & $x$ & $<0.5 \%$ & $x$ & $x$ \\
\hline PLA Horná Orava & $6 \%$ & $x$ & $<0.5 \%$ & $-7 \%$ & $x$ & $x$ & $x$ & $-12 \%$ & $1 \%$ & $<0.5 \%$ & $10 \%$ & $11 \%$ \\
\hline PLA Kysuce & $1 \%$ & $x$ & $x$ & $x$ & $x$ & $x$ & $x$ & $27 \%$ & $x$ & $<0.5 \%$ & $16 \%$ & $-27 \%$ \\
\hline PLA Latorica & $x$ & $x$ & $x$ & $5 \%$ & $x$ & $x$ & $x$ & $-4 \%$ & $<0.5 \%$ & $x$ & $x$ & $x$ \\
\hline PLA Malé Karpaty & $<0.5 \%$ & $<0.5 \%$ & $x$ & $<0.5 \%$ & $x$ & $x$ & $x$ & $-18 \%$ & $x$ & $-2 \%$ & $-4 \%$ & $7 \%$ \\
\hline PLA Pol'ana & $<0.5 \%$ & $x$ & $x$ & $x$ & $x$ & $x$ & $x$ & $-25 \%$ & $x$ & $x$ & $58 \%$ & $-9 \%$ \\
\hline PLA Ponitrie & $x$ & $x$ & $x$ & $x$ & $x$ & $x$ & $x$ & $-9 \%$ & $x$ & $x$ & $29 \%$ & $3 \%$ \\
\hline PLA Strážovské vrchy & $x$ & $x$ & $x$ & $x$ & $<0.5 \%$ & $x$ & $x$ & $3 \%$ & $x$ & $x$ & $10 \%$ & $<0.5 \%$ \\
\hline PLA Štiavnické vrchy & $<0.5 \%$ & $x$ & $x$ & $x$ & $x$ & $x$ & $x$ & $-5 \%$ & $x$ & $<0.5 \%$ & $6 \%$ & $<0.5 \%$ \\
\hline PLA Vihorlat & $2 \%$ & $x$ & $x$ & $x$ & $<0.5 \%$ & $x$ & $x$ & $-16 \%$ & $x$ & $<0.5 \%$ & $8 \%$ & $<0.5 \%$ \\
\hline PLA Východné Karpaty & $x$ & $x$ & $x$ & $x$ & $x$ & $x$ & $x$ & $-52 \%$ & $x$ & $x$ & $21 \%$ & $4 \%$ \\
\hline PLA Záhorie & $1 \%$ & $5 \%$ & $x$ & $<0.5 \%$ & $x$ & $x$ & $x$ & $-10 \%$ & $x$ & $x$ & $11 \%$ & $7 \%$ \\
\hline NP Malá Fatra & $<0.5 \%$ & $<0.5 \%$ & $x$ & $x$ & $-2 \%$ & $x$ & $x$ & $5 \%$ & $2 \%$ & $-8 \%$ & $23 \%$ & $-9 \%$ \\
\hline NP Muránska planina & $x$ & $x$ & $x$ & $x$ & $-1 \%$ & $x$ & $x$ & $-8 \%$ & $x$ & $x$ & $36 \%$ & $-17 \%$ \\
\hline NP Nízke Tatry & $<0.5 \%$ & $x$ & $x$ & $x$ & $<0.5 \%$ & $x$ & $x$ & $42 \%$ & $4 \%$ & $-9 \%$ & $11 \%$ & $-45 \%$ \\
\hline NP Poloniny & $<0.5 \%$ & $x$ & $x$ & $x$ & $x$ & $x$ & $x$ & $-35 \%$ & $x$ & $x$ & $27 \%$ & $<0.5 \%$ \\
\hline NP Slovenský Kras & $<0.5 \%$ & $x$ & $x$ & $x$ & $2 \%$ & $x$ & $x$ & $11 \%$ & $x$ & $<0.5 \%$ & $21 \%$ & $-1 \%$ \\
\hline NP Slovenský Raj & $<0.5 \%$ & $x$ & $x$ & $x$ & $-1 \%$ & $x$ & $x$ & $17 \%$ & $x$ & $x$ & $9 \%$ & $-23 \%$ \\
\hline NP Vel'ká Fatra & $x$ & $x$ & $x$ & $x$ & $1 \%$ & $x$ & $x$ & $8 \%$ & $<0.5 \%$ & $-5 \%$ & $19 \%$ & $-26 \%$ \\
\hline NP Pieniny & $x$ & $x$ & $x$ & $x$ & $x$ & $x$ & $x$ & $1 \%$ & $x$ & $x$ & $11 \%$ & $17 \%$ \\
\hline Tatra NP & $<0.5 \%$ & $x$ & $x$ & $x$ & $<0.5 \%$ & $-1 \%$ & $x$ & $48 \%$ & $5 \%$ & $-7 \%$ & $1 \%$ & $-44 \%$ \\
\hline
\end{tabular}


sitional woodland-shrub was transformed into deciduous and mixed forests. Both cases, correspond to succession processes, where over-harvested or degraded forest areas have overgrown over time and have been transformed into young forests. However, it does not have to be just a succession. Artificial reforestation is mainly used in habitats where the natural regeneration is slowed down, i.e. if the mother stand is missing or has an unsuitable species composition or poor quality, or on large calamitous areas. Artificial regeneration is often a tool to ensure the continuity of the forest in larger and more continuous calamitous areas. An obligation to afforest any clearing within two years from its origin, three years if protective forest stands are concerned, comes from the Act No. 326/2005 Coll. on forests (Zákon o lesoch 2005). The state authorities may extend this period by another two years in case of an expected natural renewal. Another obligation is to secure the forest stand from 2 to 10 years after the end of the afforestation period.

The same process, when the share of transitional woodland-shrub (CLC 324) decreases at the expense of forest land cover classes is also visible in the PLAs Dunajské luhy, Poloniny, and Polana. Succession processes are also reflected by the increase of permanent grasslands in the NP Slovenský kras. The opposite process, when the share of transitional woodland-shrub increases and the share of forest decreases, was recorded in the PLA Kysuce, the NPs Nízke Tatry, Slovenský raj and Tatra. Transitional woodland-shrub is a class which contains young forest trees (deciduous and coniferous), planted after loggings or various calamities, as well as forest nurseries, forest formations with natural development, shrub formations on abandoned meadows, pastures and forest clearings under high-voltage power lines (Feranec and Otahel' 2001). Due to the loss of forest cover, this landscape ceased to fulfill its essential functions. Consequently, the ecological stability of the landscape is disrupted, which is manifested in various disturbances, including landslides, floods, and endangering of wild animals by the reduction of their natural habitats. The most significant change in the urbanized (built-up) areas was observed in the PLA Dunajské Luhy. However, it is necessary to note

Continuation of table 3 .

\begin{tabular}{|c|c|c|c|c|c|c|c|c|c|c|c|c|c|}
\hline 311 & 243 & 242 & 231 & 222 & 221 & 211 & 142 & 141 & 133 & 132 & 131 & 121 & 112 \\
\hline $15 \%$ & $-8 \%$ & $2 \%$ & $1 \%$ & $<0.5 \%$ & $x$ & $-4 \%$ & $<0.5 \%$ & $x$ & $x$ & $x$ & $x$ & $x$ & $2 \%$ \\
\hline $26 \%$ & $-6 \%$ & $<0.5 \%$ & $-19 \%$ & $x$ & $-1 \%$ & $3 \%$ & $x$ & $x$ & $x$ & $x$ & $<0.5 \%$ & $x$ & $-2 \%$ \\
\hline $52 \%$ & $-6 \%$ & $<0.5 \%$ & $3 \%$ & $-1 \%$ & $x$ & $1 \%$ & $1 \%$ & $x$ & $-12 \%$ & $-1 \%$ & $x$ & $<0.5 \%$ & $<0.5 \%$ \\
\hline $6 \%$ & $-7 \%$ & $12 \%$ & $-11 \%$ & $x$ & $x$ & $-9 \%$ & $<0.5 \%$ & $x$ & $x$ & $x$ & $x$ & $<0.5 \%$ & $<0.5 \%$ \\
\hline $1 \%$ & $-4 \%$ & $4 \%$ & $-18 \%$ & $x$ & $x$ & $-1 \%$ & $<0.5 \%$ & $x$ & $<0.5 \%$ & $x$ & $x$ & $<0.5 \%$ & $1 \%$ \\
\hline $34 \%$ & $-4 \%$ & $-1 \%$ & $-15 \%$ & $x$ & $<0.5 \%$ & $-14 \%$ & $x$ & $x$ & $x$ & $x$ & $<0.5 \%$ & $<0.5 \%$ & $-1 \%$ \\
\hline $22 \%$ & $<0.5 \%$ & $<0.5 \%$ & $-1 \%$ & $<0.5 \%$ & $-1 \%$ & $-3 \%$ & $<0.5 \%$ & $x$ & $<0.5 \%$ & $x$ & $<0.5 \%$ & $<0.5 \%$ & $<0.5 \%$ \\
\hline$-13 \%$ & $-2 \%$ & $x$ & $-9 \%$ & $x$ & $x$ & $-1 \%$ & $x$ & $x$ & $x$ & $x$ & $x$ & $<0.5 \%$ & $x$ \\
\hline$-17 \%$ & $-1 \%$ & $<0.5 \%$ & $-2 \%$ & $<0.5 \%$ & $<0.5 \%$ & $-4 \%$ & $1 \%$ & $x$ & $x$ & $x$ & $<0.5 \%$ & $x$ & $<0.5 \%$ \\
\hline$-5 \%$ & $-4 \%$ & $-1 \%$ & $-5 \%$ & $x$ & $x$ & $1 \%$ & $x$ & $x$ & $x$ & $x$ & $x$ & $x$ & $1 \%$ \\
\hline $12 \%$ & $-13 \%$ & $<0.5 \%$ & $1 \%$ & $<0.5 \%$ & $<0.5 \%$ & $-1 \%$ & $<0.5 \%$ & $<0.5 \%$ & $x$ & $<0.5 \%$ & $<0.5 \%$ & $<0.5 \%$ & $<0.5 \%$ \\
\hline $11 \%$ & $-2 \%$ & $1 \%$ & $-2 \%$ & $x$ & $x$ & $-2 \%$ & $x$ & $x$ & $x$ & $x$ & $x$ & $2 \%$ & $-1 \%$ \\
\hline $42 \%$ & $-7 \%$ & $<0.5 \%$ & $-7 \%$ & $x$ & $x$ & $-1 \%$ & $x$ & $x$ & $x$ & $x$ & $x$ & $x$ & $<0.5 \%$ \\
\hline$-6 \%$ & $-4 \%$ & $<0.5 \%$ & $8 \%$ & $<0.5 \%$ & $<0.5 \%$ & $-12 \%$ & $<0.5 \%$ & $x$ & $x$ & $x$ & $x$ & $<0.5 \%$ & $<0.5 \%$ \\
\hline$-6 \%$ & $-3 \%$ & $2 \%$ & $-5 \%$ & $x$ & $x$ & $<0.5 \%$ & $<0.5 \%$ & $x$ & $x$ & $x$ & $<0.5 \%$ & $x$ & $<0.5 \%$ \\
\hline $1 \%$ & $1 \%$ & $x$ & $-11 \%$ & $x$ & $x$ & $<0.5 \%$ & $x$ & $x$ & $x$ & $x$ & $<0.5 \%$ & $<0.5 \%$ & $<0.5 \%$ \\
\hline$-1 \%$ & $<0.5 \%$ & $x$ & $-3 \%$ & $x$ & $x$ & $<0.5 \%$ & $1 \%$ & $x$ & $x$ & $x$ & $x$ & $x$ & $<0.5 \%$ \\
\hline $26 \%$ & $-7 \%$ & $x$ & $-11 \%$ & $x$ & $x$ & $<0.5 \%$ & $x$ & $x$ & $x$ & $x$ & $x$ & $x$ & $<0.5 \%$ \\
\hline$<0.5 \%$ & $-5 \%$ & $<0.5 \%$ & $-25 \%$ & $x$ & $-1 \%$ & $-2 \%$ & $x$ & $x$ & $x$ & $x$ & $<0.5 \%$ & $<0.5 \%$ & $<0.5 \%$ \\
\hline $10 \%$ & $2 \%$ & $x$ & $-14 \%$ & $x$ & $x$ & $-1 \%$ & $-1 \%$ & $x$ & $x$ & $x$ & $x$ & $x$ & $<0.5 \%$ \\
\hline $10 \%$ & $<0.5 \%$ & $<0.5 \%$ & $-6 \%$ & $x$ & $x$ & $<0.5 \%$ & $-1 \%$ & $x$ & $x$ & $x$ & $<0.5 \%$ & $x$ & $<0.5 \%$ \\
\hline$<0.5 \%$ & $-22 \%$ & $<0.5 \%$ & $-7 \%$ & $x$ & $x$ & $1 \%$ & $x$ & $x$ & $x$ & $x$ & $x$ & $x$ & $<0.5 \%$ \\
\hline$<0.5 \%$ & $<0.5 \%$ & $<0.5 \%$ & $-2 \%$ & $x$ & $x$ & $<0.5 \%$ & $<0.5 \%$ & $x$ & $x$ & $x$ & $x$ & $x$ & $<0.5 \%$ \\
\hline
\end{tabular}


that this area was not been categorized as a PLA in 1990. The construction of the Gabćíkovo waterworks was carried out in this area in the 1980s and 1990s. However, the system of aggradation embankments and accumulation depressions with a dense network of river distributaries was created before human interventions into the natural hydrological regime of the Danube River. The Dunajske Luhy was declared as Protected Landscape Area only in 1998, and the formerly built-up areas are nowadays mainly water bodies, permanent grasslands, agricultural areas, or deciduous forests (Feranec et al. 2002).

We have focused on the identification of processes taking place in the landscape within the dynamics of land cover classes, the so-called »land cover flows «. We have identified the dominant sub-processes based on the percentage of all changes in every protected area, i.e., the process with the highest percentage (Table 4).

Nine dominant sub-processes, which can be assigned to five land cover flows, have been identified (Figure 5).

LCF71 - is the most frequent dominant sub-process in Slovakian large protected areas. It represents the conversion of transitional woodland-shrubs to forests, i.e., the secondary succession on forest clearings. This sub-process was dominant in eight protected areas. Altogether three types of changes were observed: Transitional woodland-shrubs were dominantly transformed into deciduous forests in the PLAs Malé Karpaty (29.54\%), Dunajské luhy (40.15\%), Vihorlat (39.89\%), Východné Karpaty (40.74\%), and the NP Poloniny (37.98\%). The transformation of transitional woodland-shrubs into coniferous forests was most evident in the PLAs Horná Orava (14.96\%) and Záhorie (10.72\%), and transformation to mixed forests was most evident in the PLA Polana (28.49\%).

LCF73 - represents the internal transformations of forests, i.e., conversions of one forest type to another (among coniferous, deciduous and mixed). Overall, two types of changes have been identified, when mixed forests were converted to deciduous forests and vice versa. These sub-processes were identified in five protected areas, most notably in the NP Malá Fatra. Specifically, this involved the conversion of CLC 311 to CLC 313. Conversion of deciduous forests to mixed forests was also dominant in the PLAs Ponitrie (29.15\%) and Strážovské vrchy (17.06\%) and the NP Slovenský kras (16.36\%).

LCF74 - the sub-process is most often caused by forest loggings or by natural forces resulting in subsequent logging. Only one sub-process was identified in the large protected areas, namely the transformation of coniferous forest into transitional woodland-shrub. This sub-process can also be described as a "transient state of the forest « and has been dominant in one PLA - PLA Kysuce and in five national parks the Tatra NP, NP Nízke Tatry, NP Slovenský raj, NP Muránska planina and NP Velká Fatra. The sub-process

Table 4: Dominant land cover flows in large protected areas.

\begin{tabular}{|c|c|c|c|c|c|}
\hline \multirow[t]{2}{*}{ Large protected area } & \multicolumn{2}{|c|}{ Dominant LCF } & \multirow[t]{2}{*}{ Large protected area } & \multicolumn{2}{|c|}{ Dominant LCF } \\
\hline & $\%$ & LCF & & $\%$ & LCF \\
\hline PLA Biele Karpaty & 16.12 & LCF73 & PLA Východné Karpaty & 40.74 & LCF71 \\
\hline PLA Cerová vrchovina & 17.79 & LCF61 & PLA Záhorie & 10.72 & LCF71 \\
\hline PLA Dunajské Luhy & 40.15 & LCF71 & NP Malá Fatra & 32.54 & LCF73 \\
\hline PLA Horná Orava & 14.96 & LCF71 & NP Muránska planina & 17.59 & LCF74 \\
\hline PLA Kysuce & 31.18 & LCF74 & NP Nízke Tatry & 52.59 & LCF74 \\
\hline PLA Latorica & 14.62 & LCF61 & NP Poloniny & 37.98 & LCF71 \\
\hline PLA Malé Karpaty & 29.54 & LCF71 & NP Slovenský kras & 16.36 & LCF73 \\
\hline PLA Pol'ana & 28.49 & LCF71 & NP Slovenský raj & 43.42 & LCF74 \\
\hline PLA Ponitrie & 29.15 & LCF73 & NP Velká Fatra & 16.17 & LCF74 \\
\hline PLA Strážovská vrchy & 17.06 & LCF73 & NP Pieniny & 20.59 & LCF523 \\
\hline PLA Štiavnické vrchy & 9.28 & LCF61 & NP Tatra & 53.55 & LCF74 \\
\hline PLA Vihorlat & 39.89 & LCF71 & & & \\
\hline
\end{tabular}


Acta geographica Slovenica, 60-2, 2020

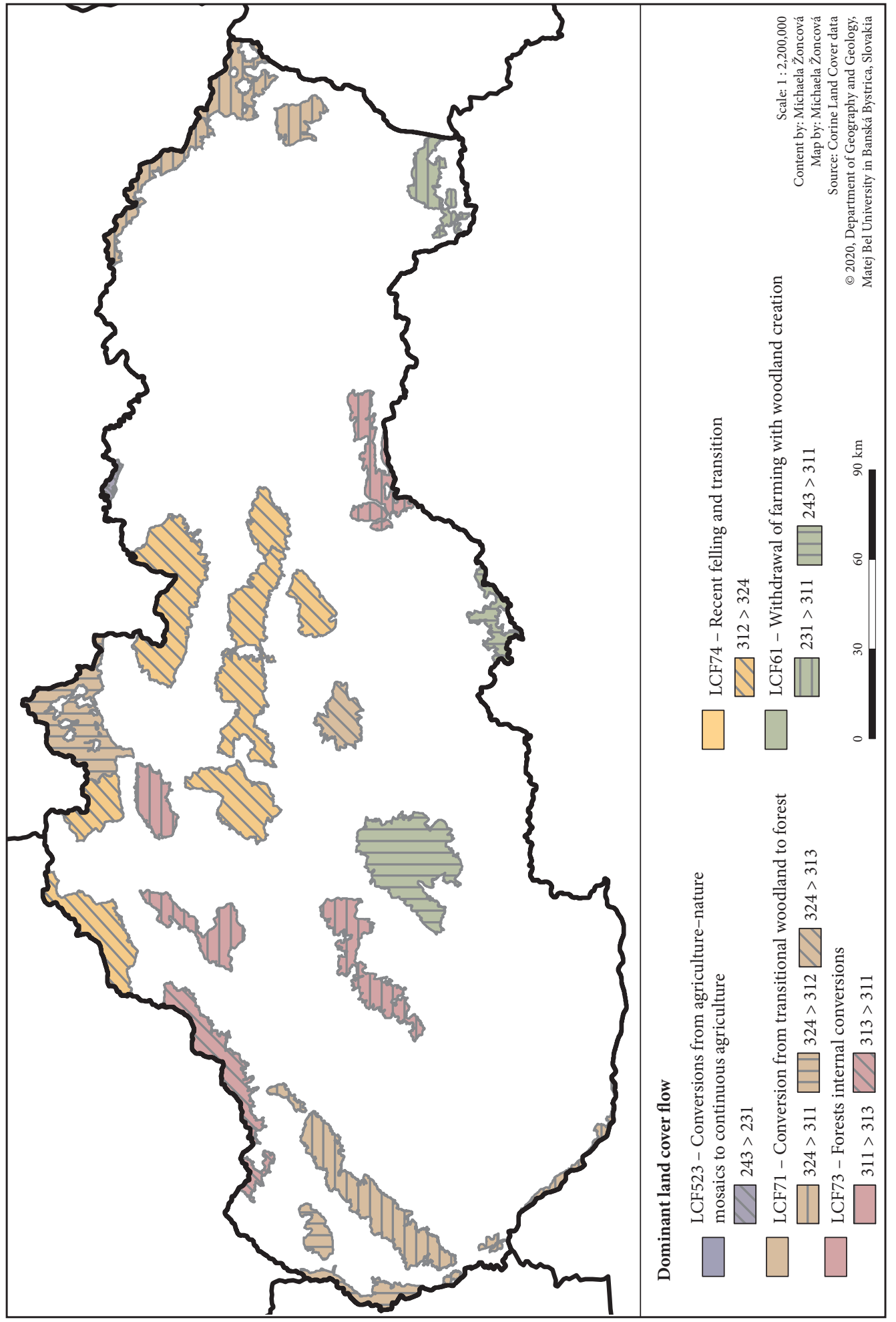


can be described as alarming, as the most significant parts of Slovakia's nature have lost a large amount of forest areas. These areas are often affected by wind disasters, with the most considerable damage being recorded in 2004 (Konôpka and Kunca 2016). The proportion of forests destroyed by wind calamities has been increasing over the past 55 years (Konôpka and Konôpka 2007).

LCF61 - This sub-process involves a secondary succession sub-process and the abandonment of agricultural land and its gradual transformation into transitional woodland-shrubs or forests. Two types of changes were identified: The class land principally occupied by agriculture, with significant areas of natural vegetation (CLC 243) was transformed into broad-leaved forest (CLC 311) in the PLA Cerová Vrchovina and the PLA Štiavnické Vrchy and pastures were transformed into broad-leaved forests (CLC 311) in the PLA Latorica. Abandonment of agricultural land is related to socio-economic changes in Slovakia and changes in traditional management (Lieskovský et al. 2015; Pazúr et al. 2014). Traditional mowing or goats and sheep grazing had prevented succession sub-processes in the past (Škodová and Gajdoš 2010).

LCF523 - the sub-process is characterized by the conversion of predominantly agricultural structures with natural elements into continuous agriculture. The sub-process was dominant only in NP Pieniny, where mainly CLC 243 was converted to CLC 231.

\subsection{Diversity and landscape stability of the large protected areas}

The landscape diversity in the observed years was calculated using the SDI. The variation of this index reflects the changes in the number of landscape feature classes and their abundance. We have also determined the level of ecological stability of the landscape (Figure 6).

SDI values ranged from 0.48 in the PLA Vihorlat to 1.84 in the PLA Záhorie in 1990. The minimum and maximum values were recorded in these areas in 2018 as well. The most significant decrease in the

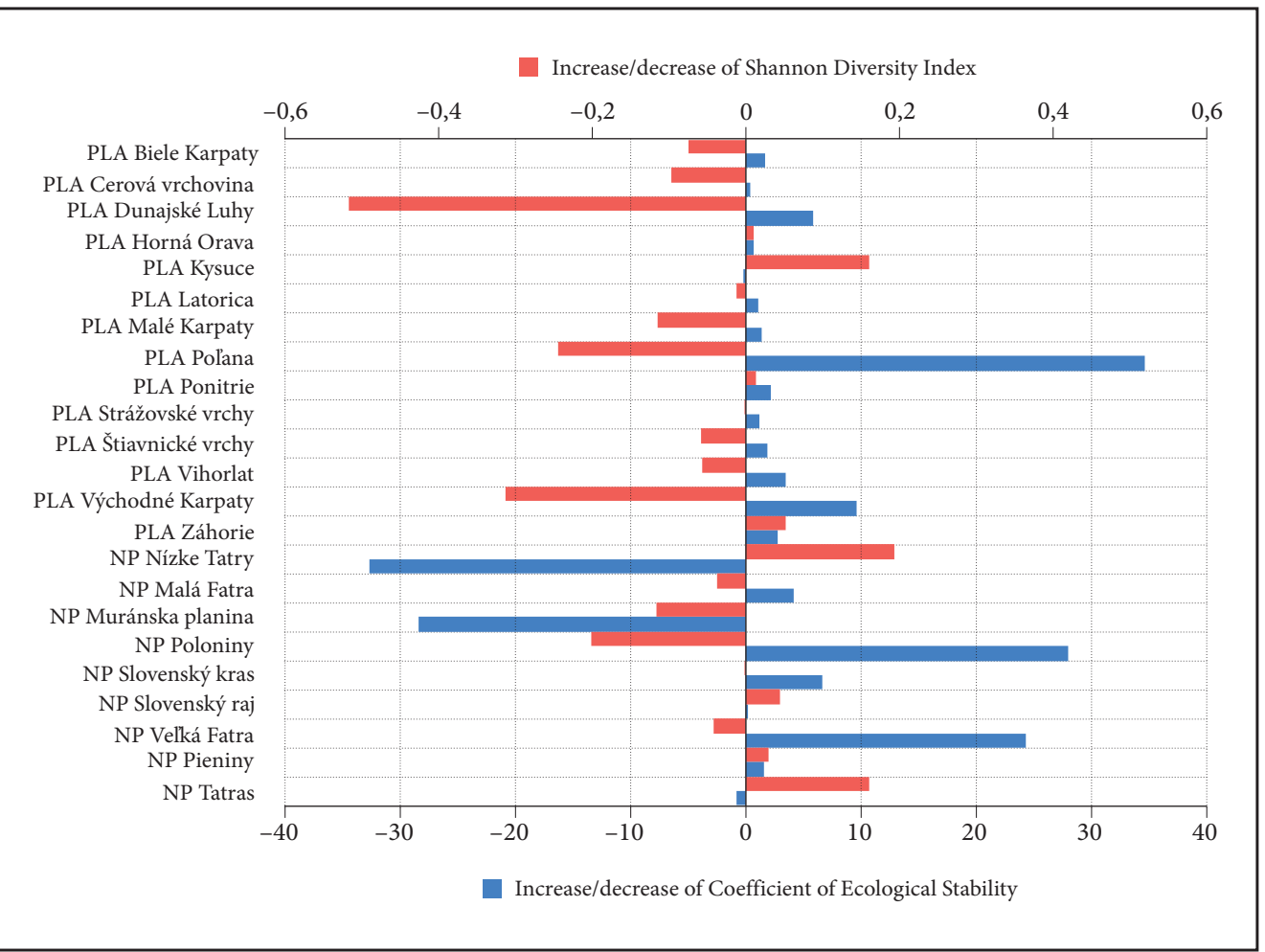

Figure 6: SDI and ESc change in the large protected areas of Slovakia between 1990 and 2018. 
SDI value, i.e., a decrease in diversity of the landscape, occurred in the PLA Dunajské Luhy. A decline in human activity-related land cover classes (construction and agricultural activity), was observed and reflected in SDI values. A significant decrease in SDI values also occurred in the PLA Východné Karpaty, where the number of land cover classes did not change, but they were unequally distributed (represented) in the landscape. On the other hand, the highest increase of SDI index occurred in the NP Nízke Tatry, the Tatra NP, and the PLA Kysuce. The areas of coniferous forests have decreased, and the areas of transitional woodland-shrubs increased in the NP Nízke Tatry due to wind calamities and subsequent logging. The CLC classes are thus represented more evenly, but in this case, the increase in SDI values suggests a higher landscape diversity. However, it is questionable whether this radical increase has a positive effect on the stability of the landscape.

We have analyzed the stability of the landscape using the coefficient of ecological stability, according to Míchal (1982). All of the protected areas in both of the monitored years reached values of the ESc index higher than 1.0, which is a result of an almost well-balanced landscape, where the technical features are in relative balance with the preserved natural structures. The ecological stability coefficient of less than 1.0 was recorded only in the PLA Latorica for the year 1990. This value indicates that the area was used intensively mainly for large-scale agricultural production, while the self-regulation processes were weakened, which caused lower ecological instability in these areas. However, the value of ESc had increased above 1.0 in this area in 2018.

Ecological stability of the landscape had decreased in four protected areas, while it increased in the others. A small, almost negligible decline occurred in the PLA Kysuce and the NP Vysoké Tatry. However, a significant decrease occurred in the NP Nízke Tatry and the NP Muránska Planina. Although ESc values still reached high levels in these areas (higher than in the other protected areas), these changes are alarming as these are areas with habitats of protected species. In the NP Muránska Planina, the greatest threat is the loss of the natural habitats of the critically endangered capercaillie (Figúr, Malina and Urban 2016). On the contrary, the most significant increase in ESc values, i.e., a significant increase in the ecological stability of the landscape, occurred in the NP Polana, the NP Poloniny, and the NP Velká Fatra.

\section{Discussion and conclusion}

In the large-scale protected areas of Slovakia, the most substantial changes occurred between transitional woodland-shrubs (CLC 324) and mixed forests (CLC 313). Changes among these classes represent an ongoing process. On the one hand, it is a process of succession, and on the other, it is a reduction of the forest area. According to Vološčuk (2010), the assessment of the secondary succession of dendroflora in the abandoned former pasture sites with permanent grassland is perceived rather negatively from the landscapes' characteristic appearance point of view. However, this process is positive, considering the ecological stability of a landscape, where forest ecosystems represent the most stable elements. In this sense, it is essential to perceive landscape diversity and stability as two different concepts. A decline in the stability of the landscape despite the increase in the landscape diversity was a frequent phenomenon. Increased landscape diversity is often a result of radical interventions in the landscape, both natural and anthropogenic. The values of landscape-ecological indices have to be interpreted very sensitively for this reason. Although the values of the SDI index have increased over the period studied, irreversible and degrading changes for the landscape occurred. The share of CLC 324 (transitional woodland-shrub) increased, while the share of CLC 312 (coniferous forests) decreased, mainly due to wind calamities and subsequent logging in the NP Nízke Tatry. Therefore, land cover classes had a more even representation in the landscape, and the landscape diversity increased. Is the increase in the landscape diversity beneficial to the landscape in this way? According to Guerra, Rosa and Pereira (2019), monitoring of land cover changes is particularly crucial in protected areas where long-term ecosystem stability is a critical aspect of conservation. We agree with Ružičková, Moravčíková and Lehotská (2009), who states that the resulting values of the landscape's diversity index do not describe the ecological stability and quality of the assessed area and do not take the internal differentiation (disaggregation) of the landscape structure features into account. The penetration of dendroflora in secondary succession into the abandoned agrarian ecosystems can cause a decrease in the value of landscape character (patterns of elements in the landscape) and can be understood as a degradation process. Secondary succession of dendroflora in grassland ecosystems can also be understood as ecological 
damage because by disrupting internal links and processes, it weakens the natural functions of permanent grassland ecosystems (Vološčuk 2010). These conditions are suitable for the spreading of non-native and invasive plant species and plant species in the form of scattered groups of shrubs and trees (David, Mojses and Boltižiar 2013). According to Šebo and Kopecká (2014), small meadows in Slovakia will almost entirely disappear due to the difficulty of their maintenance. This problem has been also observed throughout other countries in Central Europe (Pruchniewicz 2017).

The second most dominant sub-process was the reduction of forest area when forest stands were converted to transitional woodland-shrubs. This class (CLC 324) can arise through an entirely different development and can thus take on completely different values of ecological stability or diversity. On the one hand, it may include areas artificially mined by heavy machinery with severely anthropogenically affected and degraded landscape. However, it may also include areas affected by wind disasters left to develop spontaneously and thus with slower but spontaneous forest regeneration. The issue of landscape management after wind disasters is still very up-to-date, and there is a constant debate about whether it is necessary to remove or leave calamity wood in the landscape. According to Urbanovičová, Miklisová and Kováč (2014), it is much more appropriate to leave the fallen wood after a wind calamity in the landscape to enable the survival of specific forest species and to preserve the diversity of forests. The wind is becoming one of the most important abiotic factors, which causes various disturbances in the landscape of Slovakia (Konôpka, Zach and Kulfan 2016). The importance of protected areas in Slovakia is also confirmed by the fact that deforestation is visible on a much smaller scale in the protected areas than in the surrounding unprotected areas (Butsic et al. 2017). For example, the difference can also be seen between the Polish and Slovak sides of the Tatra National Park, with radical differences in the opinions on logging in the national parks, on bark beetles, and large predators hunting (Janiga et al. 2012). A new law entered into force in Slovakia on 1 January 2020, strengthening the competence of the State Nature Conservancy of Slovak Republic. Logging will not be possible in the protected areas with the third and higher degree of protection without its consent, while so far, they have had such powers only in areas with the fifth degree of protection.

Based on the results obtained, we can conclude that the CLC database is a suitable data source to analyze main land cover changes in Slovakia in larger areas, but some classes may also include diametrically different types of landscapes (e.g., CLC 324) that perform different functions. However, the CLC database also has its negatives (Jovanović, Milanovic and Zorn 2018) and is not suitable for monitoring current changes (5-10 years) and for monitoring changes in small areas, as the Minimum Mapping Unit (MMU) is 25 ha. Also, the values of landscape ecological metrics should be sensitively interpreted because it does not take the internal differentiation of land cover classes into account. In the future, it is necessary to focus on the proper management of the landscape after wind calamities, as these are the primary triggers of the significant landscape changes in protected areas of Slovakia. Although the process associated with new construction activity did not predominate in any of the protected areas, purposeful innovations in line with the principles of sustainable development are still necessary for the development of these areas (Lencsésová, Gajdošík and Gúčik 2015).

Therefore, we agree with Paunović and Jovanović (2019), that it is necessary to put a special emphasis on exchange of best practices and improvement of the quality of all sustainable tourism elements from other countries.

ACKNOWLEDGMENT: This work was supported by the Slovak Research and Development Agency under Contract no. APVV-18-0185 Land-use changes of Slovak cultural landscape and prediction of its further development.

\section{References}

Boltižiar, M. 2010: Analysis of the development of heterogeneity and chosen qualities of the spots of the structure of alpine land (on the example of chosen model land of High Tatra). Folia geographica 51-16.

Butsic, V., Munteanu, C., Griffiths, P., Knorn, J., Radeloff, V. C., Lieskovský, J., Mueller, D., Kuemmerle, T. 2017: The effect of protected areas on forest disturbance in the Carpathian Mountains 1985-2010. Conservation Biology 31-3. DOI: https://doi.org/10.1111/cobi.12835 
David, S., Mojses, M., Boltižiar, M. 2013: How and why is Changing the Landscape of Dry Polder Beša? Životné prostredie 47-3.

DeFries, R., Hansen, A., Turner, B., Reid, R., Liu, J. 2007: Land Use Change Around Protected Areas: Management to Balance Human Needs and Ecological Function. Ecological applications 17-4. DOI: https://doi.org/10.1890/05-1111

Deriaz, J., Ciglič, R., Ferk, M., Loczy, D. 2019: The Influence of Different Levels of Data Detail on Land use Change Analyses: A Case Study of Franciscan Cadastre for a Part of the Pannonian Hills, Slovenia. European Countryside 11-3. DOI: https://doi.org/10.2478/euco-2019-0019

Feranec, J., Jaffrain, G., Soukup, J., Hazeu, G. W. 2010: Determining changes and flows in European landscapes 1990-2000 using CORINE Land Cover data. Applied Geography 30-1. DOI: https://doi.org/ 10.1016/j.apgeog.2009.07.003

Feranec, J., Súri, M., Cebecauer, T., Otahel, J. 2002: Methodological aspects of landscape changes detection and analysis in Slovakia applying the CORINE Land Cover databases. Geografický časopis 53-3.

Feranec, K., Otahel, J. 2001: Krajinná pokrývka Slovenska. Bratislava.

Figúr, J., Malina, R., Urban, P. 2016: Hlucháň hôrny (Tetrao Urogallus) v chránenom vtáčom území Muránska planina - Stolica. Ochrana prírody 27.

Gabrovec, M., Ortar, J., Pavšek, M., Zorn, M., Triglav Čekada, M. 2013: The Triglav Glacier between the years 1999 and 2012. Acta geographica Slovenica 53-2. DOI: https://doi.org/10.3986/AGS53202

Gajdoš, A., Klaučo, M., Škodová, M. 2012: Ecological significance of the forest ecotone vegetation in the Starohorské Hills. Geographical journal 64.

Geldmann, J., Joppa, L. N., Burgess, N. D. 2014: Mapping change in human pressure globally on land and within protected areas. Conservation Biology 28-6. DOI: https://doi.org/10.1111/cobi.12332

Guerra, C. A., Rosa, I. M. D., Pereira, H. M. 2019: Change versus stability: are protected areas particularly pressured by global land cover change? Landscape Ecology 34. DOI: https://oi.org/10.1007/s10980019-00918-4

Haines-Young, R., Weber, J. L. 2006: Land Account for Europe 1990-2000. Towards integrated land and ecosystem accounting. EEA Report No 11/2006. Internet: http://www.eea.europa.eu/publications/eea_ report_2006_11 (14.11.2019).

Hamad, R., Kolo, K., Balzter, H. 2018: Land cover changes induced by demining operations in HalgurdSakran national park in the Kurdistan region of Iraq. Sustainability 10-7. DOI: https://doi.org/10.3390/ su 10072422

Janiga, M., Markuljaková, K., Mahút, O., Pogányová, P., Kohútová, Z., Šulavík, J., Boháčová, A., Herian, N., Ivaničová, Z., Veselská, M., Štefancová, D., Ištoňa, M., Tichý, P., Kvanda, J., Mikoláš, P., Griga, F., Chovancová, S., Adamová, M., Lištiaková, E., Gašperanová, J., Kozárik, V., Hruška, D., Podracká, M., Masaryk, M., Novisedláková, M., Thomková, J., Kmecík, J., Karkoszková, V., Bugáň, P., Šudila, M., Richtárech, P. 2012: Revenues of stakeholders in the national parks and landscape protection areas of the Slovak Republic. Oecologia Montana 21-1.

Izakovičová, Z. 2012: Environmental Quality of the Slovak Rural Settlements. Životné prostredie 46- 4.

Janík, T., Romportl, D. 2018: Recent land cover change after the Kyrill windstorm in the Šumava NP. Applied Geography 97. DOI: https://doi.org/10.1016/j.apgeog.2018.06.006

Jansen, L. J. M. 2006: Harmonization of land use class sets to facilitate compatibility and comparability of data across space and time. Journal of Land Use Science 1, 2-4. DOI: https://doi.org/10.1080/17474230601079241

Jovanović, M. M., Milanović, M. M., Zorn, M. 2018: The use of NDVI and CORINE Land Cover databases for forest management in Serbia. Acta geographica Slovenica 58-1. DOI: https://doi.org/10.3986/AGS.818

Klaučo, M., Weis, K., Gregorová, B., Anstead, L. 2014: Geografické informačné systémy 3. Banská Bystrica.

Klaučo, M., Weis, K., Stankov, U., Arsenovic, D., Marković, V. 2012: Ecological significance of land-cover based on interpretation of human-tourism impact. A case from two different protected areas (Slovakia and Serbia). Carpathian Journal of Earth and Environmental Sciences 7-3.

Kňazovičová, L., Chasníková, S., Novák, J., Barančok, P. 2018: Impacts of ski pistes preparation and ski tourism on vegetation. Ekológia 37-2. DOI: https://doi.org/10.2478/eko-2018-0014

Köhler, R., Olschofsky, K., Gerard, F. 2006: Land cover change in Europe from the 1950'ies to 2000. Hamburg.

Konôpka, B., Zach, P., Kulfan, J. 2016: Wind - an important ecological factor and destructive agent in forests. Lesnícky časopis - Forestry Journal 62-2. DOI: https://doi.org/10.1515/forj-2016-0013

Konôpka, J., Konôpka, B. 2007: Vývoj náhodnej tažby dreva na Slovensku a jej prognóza pre vietor, sneh a námrazu do roku 2025. Lesnícky časopis - Forestry Journal 53-4. 
Konôpka, J., Kunca, A. 2016: Náhodná tažba v rokoch 1960 - 2014. Výskyt škodlivých činitelov v lesoch Slovenska v rokoch 1960 - 2014, v roku 2015 a prognóza ich vývoja. Zvolen.

Krajewski, P. 2019: Monitoring of Landscape Transformations within Landscape Parks in Poland in the 21st Century. Sustainability 11-8. DOI: https://doi.org/10.3390/su11082410

Kumar, M., Denis, D. M., Singh S. K., Szabó, S., Suryavanshi, S. 2018: Landscape metrics for assessment of land cover change and fragmentation of a heterogeneous watershed. Remote Sens Applications: Society and Environment 10. DOI: https://doi.org/10.1016/j.rsase.2018.04.002

Lambin, E.F., Rounsevell, M.D.A., Geist, H.J. 2000: Are agricultural land-use models able to predict changes in land-use intensity? Agriculture, Ecosystems \& Environment, 82-1.

Lencsésová, Z., Gajdošík, T., Gúčik, M. 2015: Ensuring the sustainable development in protected areas in Slovakia. Ekonomia I Srodowisko 55-4.

Li, Z., Li, X., Ma, W. Y. A., Wang, J. 2004: Land-use change analysis in Yulin prefecture, northwestern China using remote sensing and GIS. International Journal of Remote Sensing 25-24. DOI: https://doi.org/ $10.1080 / 01431160412331291206$

Lieskovský, J., Bezák, P., Špulerová, J., Lieskovský, T., Koleda, P., Dobrovodská, M., Bürgi, M., Gimmi, U. 2015: The abandonment of traditional agricultural landscape in Slovakia - Analysis of extent and driving forces. Journal of Rural Studies 37. DOI: https://doi.org/10.1016/j.jrurstud.2014.12.007

Margules, C. R., Pressey, R. L., Williams, P. H. 2002: Representing biodiversity: Data and procedures for identifying priority areas for conservation. Journal of Biosciences 27. DOI: https://doi.org/10.1007/ BF02704962

Martin, E. H., Jensen, R. R., Hardin, P. J., Kisingo, A. W., Shoo, R. A., Eustace, A. 2019: Assessing changes in Tanzania's Kwakuchinja Wildlife Corridor using multitemporal satellite imagery and open source tools. Applied Geography 110. DOI: https://doi.org/10.1016/j.apgeog.2019.102051

Martinez del Castillo, E., García-Martin, A., Longares Aladrén, L. A., de Luis, M. 2015: Evaluation of forest cover change using remote sensing techniques and landscape metrics in Moncayo Natural Park (Spain). Applied Geography 62. DOI: https://doi.org/10.1016/j.apgeog.2015.05.002

Míchal, I. 1982: Principy krajinářského hodnocení území. Architektúra a urbanizmus XVI/Z. Bratislava.

Olahová, J., Vojtek, M., Boltižiar, M. 2013: Application of geoinaromation technologies for the assesment of landscape structure using landscape-ecological indexes (case study of the Handlová landslide). Tájökológiai Lapok 11-2.

Paunović, I., Jovanović, V. 2019: Sustainable mountain tourism in word and deed: A comparative analysis in the macro regions of the Alps and the Dinarides. Acta geographica Slovenica 59-2. DOI: https:/doi.org/ 10.3986/AGS.4630

Pazúr, R., Bolliger, J. 2017: Land changes in Slovakia: Past processes and future directions. Applied Geography 85. DOI: https://doi.org/10.1016/j.apgeog.2017.05.009

Pazúr, R., Lieskovský, J., Feranec, J., Otahel, J. 2014: Spatial determinants of abandonment of large-scale arable lands and managed grasslands in Slovakia during the periods of post-socialist transition and European Union accession. Applied Geography 54. DOI: https://doi.org/10.1016/j.apgeog.2014.07.014

Perdigao, V., Christensen, S. 2000: The LACOAST atlas: Land cover changes in European coastal zones. Milan.

Pruchniewicz, D. 2017: Abandonment of traditionally managed mesic mountain meadows affects plant species composition and diversity. Basic and Applied Ecology 20. DOI: https://doi.org/10.1016/ j.baae.2017.01.006

Radeloff, V. C., Gutman, G. 2017: Land-Cover and Land-Use Changes in Eastern Europe after the Collapse of the Soviet Union in 1991. Cham. DOI: https://doi.org/10.1007/978-3-319-42638-9

Ribeiro, D., Šmid Hribar, M. 2019: Assessment of land-use changes and their impacts on ecosystem services in two Slovenian rural landscapes. Acta Geographica Slovenica 59-2. DOI: https://doi.org/10.3986/ AGS.6636

Rodríguez-Rodríguez, D., Martínez-Vega, J., Echavarría, P. 2019: A twenty year GIS-based assessment of environmental sustainability of land use changes in and around protected areas of a fast developing country: Spain. International Journal of Applied Earth Observation and Geoinformation 74. DOI: https://doi.org/10.1016/j.jag.2018.08.006 
Rušnák, T., Izsóff, M., Lieskovský, J. 2017: Exploitation of geotagged photos as an indicator of visit rate and visual attractiveness of tourism objects. Topical issues of tourism, Conference Proceedings of the International Conference, Jihlava.

Ružičková, J., Moravčíková, Z., Lehotská, B. 2009: Ochrana a využívanie krajiny. Bratislava.

Sláviková, D., Slávik, D. 2006: Is it Possible to Work Calamity in a Protected Area by Consensus? Životné Prostredie 40.

Stott, A., Haines-Young, E. 1998: Linking land cover, intensity of use and botanical diversity in an accounting framework in the UK. Environmental accounting in theory and practice. Dordrecht.

Šebo, D., Kopecká, M. 2014: Abandonment of agricultural landscape after 1989: A case study from the Považie Region, Slovakia. Geografický časopis 66-4.

Škodová, M., Gajdoš, A. 2010: Dynamics of changes in the structure of the forest edge in Slovakia. Studia Geographica I. Annales Uniwersitet Paedagogicae Cracoviensis 93-1.

Štátny zoznam osobitne chránených častí prírody SR, 2020. Internet: http://uzemia.enviroportal.sk/about (4. 6. 2020).

Urbanc, M., Printsmann, A., Palang, H., Skowronek, E., Woloszyn, W., Konkoly Gyuró, É. 2004: Comprehension of rapidly transforming landscapes of Central and Eastern Europe in the 20th century. Acta geographica Slovenica 44-2. DOI: https://doi.org/10.3986/AGS44204

Urbanovičová, V., Miklisová, D., Kováč, L. 2014: Forest disturbance enhanced the activity of epedaphic collembola in windthrown stands of the High Tatra mountains Journal of Mountain Science 11. DOI: https://doi.org/10.1007/s11629-013-2736-z

Vološčuk, I. 2010: Vplyv sukcesie rastlinstva na charakteristický vzhlad krajiny. Enviroportál 28-6.

Zafar, S. M. 2014: Spatio-temporal analysis of land cover/land use changes using geoinformatics (A case study of Margallah Hills National Park). Indian Journal of Science and Technology 7.

Zákon o lesoch. Zákon Slovenskej republiky 326/2005. Bratislava.

Zákon o ochrane prírody a krajiny. Zákon Slovenskej republiky 543/2002. Bratislava. 